Volume 11, Nomor 2, November 2019, pp 289-307 Copyright (C) 2017 Jurnal Akuntansi Maranatha, Program Studi Akuntansi, Fakultas Ekonomi, Universitas Kristen Maranatha. ISSN 2085-8698 | e-ISSN 2598-4977. http://journal.maranatha.edu

\title{
Simulasi Perubahan Persyaratan Kredit Dalam Upaya Meningkatkan Laba
}

\author{
Felina Kusnakhin \\ Fakultas Ekonomi Program Studi Magister Manajemen-Univ. Katolik Parahyangan \\ (Jl. Merdeka No.30, Bandung, 40117) \\ fkusnakhin@gmail.com
}

\begin{abstract}
Financial management involves understanding and transferring assets and liabilities of the company, including freedom of use of profits, liability and debt, cash flow and profitability. Meanwhile every strategy exposes business people to trade-offs that present benefits and risks. Selling on credit is one of the strategies that helps companies to increase sales and maintain customer relationships, but on the other hand it presents the risk of billing. This research is intended to provide a solution to the problem of the duration billing.The research method used in this study is a descriptive study method. A research method to describe the characteristics of people, events, or situations. In this study, the research object in question is $C V$. Y. The research began with calculating the effect of trade receivables on the company's financial statements, especially on the value of net cash increases. The study continued with a credit simulation of changes in credit terms by setting cash discounts, cash discount periods and payment limits. As for each credit terms of the simulation produces different effects on several costs associated. As for credit terms, too tight credit terms will cause a loss of sales and too loose credit terms will lead to bad expense. The simulation showed that every credit terms will lead to different profit projection. Overall, the results of the simulation research show that every credit terms will increase the profit.
\end{abstract}

Keywords: Credit Terms, Sales on Credit, Profits 


\section{Pendahuluan}

Penting bagi perusahaan untuk tetap kompetitif, perlu menjaga setiap fungsional berjalan efektif. Manajemen keuangan melibatkan pemahaman dan pengendalian dalam mengalokasikan seluruh aset dan kewajiban perusahaan, memantau pembiayaan operasional. Sebagai perusahaan yang bergerak sebagai distributor berbagai jenis peralatan rumah tangga (sebagai jenis pemain ketiga), CV.Y melakukan penjualan secara kredit.
Penjualan tunai dilakukan untuk menjaga keseimbangan antara penjualan dan kecepatan pembayaran. Sementara penjualan kredit ditujukan untuk menjaga hubungan dengan konsumen agar tidak beralih kepada pesaing lain, sekaligus meningkatkan penjualan. Gambar 1 menunjukkan data penjualan yang dilakukan oleh CV.Y selama 5 tahun terakhir terhitung tahun 2013 hingga tahun 2017.

\section{E Penjualan Tunai E Penjualan Kredit}

15.000.000.000

10.818.750.28510.443.755.423

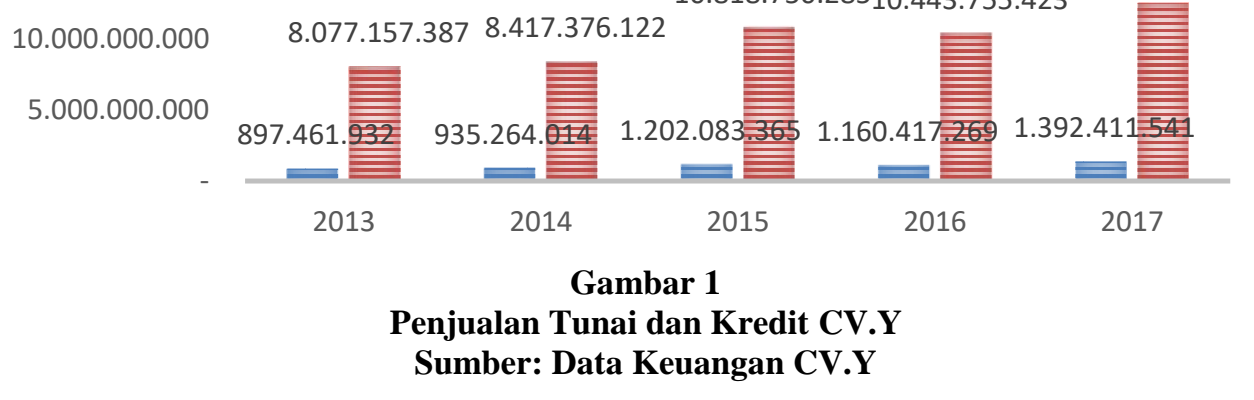

Gambar 1 menunjukkan penjualan yang dilakukan oleh perusahaan bertitik berat pada penjualan secara kredit. Penjualan secara kredit membantu CV.Y meningkatkan penjualan serta menjaga hubungan dengan konsumen namun di sisi lain menghadirkan risiko penagihan dalam hal ini adalah risiko piutang. Seiring dengan perkembangan perusahaan dan bertambahnya jumlah konsumen, Perusahaan merasakan semakin sulitnya untuh menagih piutang yang menimbulkan opportunity lost berupa penurunan keuntungan (laba) yang diperoleh.

Penerimaan Seharusnya E Penerimaan Sesungguhnya

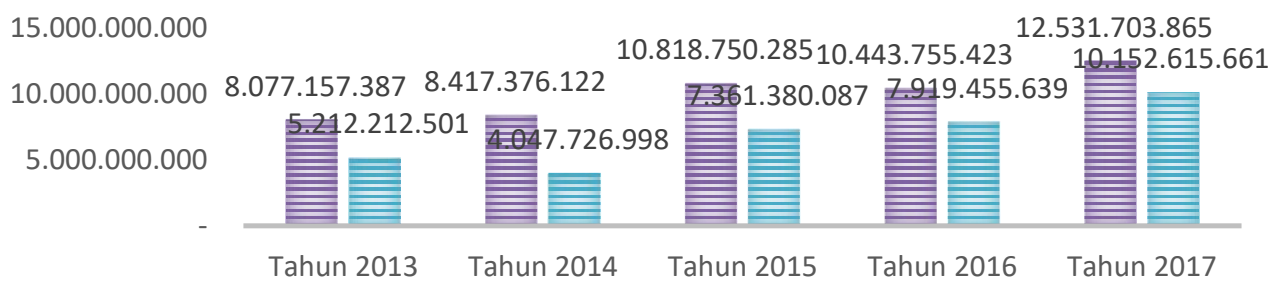

Gambar 2

Penerimaan Seharusnya dan Penerimaan Sesungguhnya atas Penjualan Kredit Sumber: Data Keuangan CV.Y 
Gambar 2 menunjukkan semakin tinggi penjualan kredit yang dilakukan perusahaan semakin rentan perusahaan terhadap penurunan keuntungan; ditunjukkan melalui penurunan penerimaan yang seharusnya didapatkan oleh perusahaan. Semakin tingginya penjualan kredit yang dilakukan, membutuhkan manajemen piutang. Manajemen piutang merupakan usaha yang penting untuk dilakukan sebab tanpa manajemen, piutang akan mencapai tingkat yang berlebihan dan dapat menyebabkan penurunan arus kas (Sundajaja, Barlian Sundjaja, 2013).

Untuk mengatasi masalah penurunan keuntungan akibat sulitnya penagihan piutang, dilakukanlah suatu penelitian simulasi perubahan persyaratan kredit berupa simulasi perubahan periode kredit. Hal ini ditujukan untuk dapat menghasilkan manajemen piutang yang tepat bagi Perusahaan.

Secara industri, rata-rata pembayaran kredit untuk electric dan kitchen ware adalah 45 hari. Sedangkan rata-rata periode tagih CV.Y adalah 107 hari. Lamanya piutang tersebut dibayarkan menimbulkan piutang ragu-ragu yang berujung pada opportunity lost berupa penurunan keuntungan. Untuk mengatasi permasalahan tersebut, dibutuhkan manajemen piutang yang disesuaikan dengan kondisi industri CV.Y.

\section{Rumusan Masalah}

Rumusan masalah dari penelitian ini, adalah:

1. Bagaimana pengaruh piutang dagang terhadap laporan keuangan CV.Y?

2. Bagaimana simulasi perubahan persyaratan kredit yang dapat diterapkan oleh CV.Y?

3. Bagaimana dampak penerapan simulasi perubahan persyaratan kredit terhadap laba?

\section{Tujuan Penelitian}

Tujuan yang ingin dicapai dari penelitian ini adalah:
1. Mengetahui pengaruh piutang dagang terhadap laporan keuangan CV.Y.

2. Mengetahui simulasi perubahan persyaratan kredit yang dapat diterapkan oleh CV.Y.

3. Mengetahui dampak penerapan simulasi perubahan persyaratan kredit terhadap laba CV.Y.

\section{Desain Penelitian}

Penelitian ini dirancang dalam bentuk berikut:

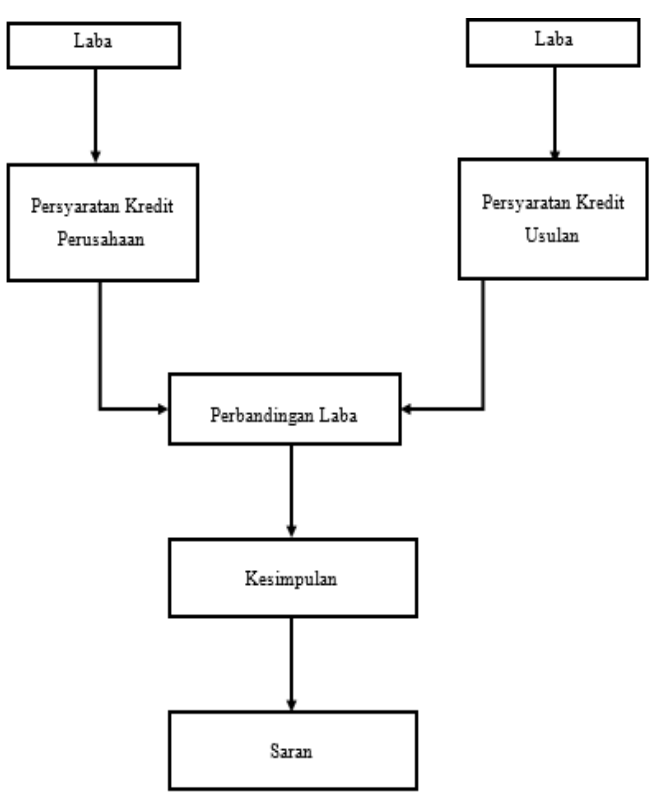

\section{Gambar 3 \\ Desain Penelitian \\ Sumber: Dokumentasi Pribadi}

Melalui laporan keuangan dapat terlihat bagaimana besarnya penjualan kredit mempengaruhi jumlah piutang. Juga dapat diketahui bagaimana besarnya piutang yang tidak diiringi dengan manajemen piutang usaha yang sesuai, mempengaruhi keuntungan yang diperoleh. Dengan demikian laba yang didapat dapat dipergunakan kembali untuk membiayai kegiatan operasional sehingga tidak mengganggu kondisi keuangan perusahaan. 
Penelitian dilakukan dengan mengumpulkan data-data berupa penjualan kredit dan kondisi piutang selama tahun 2013 hingga Tahun 2017. Penelitian dilanjutkan dengan simulasi kredit melalui perubahan syarat kredit dengan menetapkan diskon tunai, periode diskon tunai, batasan akhir pembayaran.

Standar kredit merupakan syarat pembayaran yang dinyatakan seperti $2 / 10$ net 30 . Hal ini berarti pembeli menerima potongan sebesar $2 \%$ dan pembayaran paling lambat dilakukan 10 hari setelah penjualan. Tetapi jika pelanggan tidak mengambil diskon tunai, maka keseluruhan pembayaran harus dilakukan dalam waktu 30 hari setelah dilakukan penjualan. Setelah melakukan simulasi perubahan syarat kredit, dilakukan perhitungan laba sebelum pajak serta membandingkan laba sebelum pajak perusahaan sebelum adanya perubahan kebijakan syarat kredit dengan perubahan kebijakan.

\section{Kerangka Teoritis}

\section{Laporan Keuangan}

Laporan keuangan merupakan salah satu bentuk komunikasi perusahaan yang menunjukkan kegiatan historis dalam satuan keuangan (Weygandt, Warfield, Kieso, 2015). Sejalan dengan definisi tersebut Sundjaja, Barlian, Sundjaja (2013) menyatakan bahwa laporan keuangan merupakan suatu laporan yang digunakan sebagai alat komunikasi antar data keuangan/aktivitas perusahaan dengan pihak yang berkepentingan. Menurut Standar Akuntansi Keuangan (SAK) per tanggal 1 Oktober 1994, laporan keuangan harus menyajikan secara wajar posisi keuangan, kinerja keuangan, perubahan ekuitas dan arus kas.

Leach dan Melicer (2015), menyatakan bahwa laporan keuangan pada umumnya terdiri dari Neraca, Laporan Laba rugi, Laporan Perubahan Modal atau Laba yang Ditahan, walaupun dalam prakteknya sering diikut sertakan beberapa laporan yang ditujukan untuk memperoleh kejelasan lebih lanjut, seperti Perhitungan Harga Pokok. Terdapat penjelasan singkat mengenai beberapa jenis laporan keuangan, diantaranya:

1. Neraca, menggambarkan posisi keuangan perusahaan pada suatu tanggal tertentu.

2. Laporan Laba Rugi, menggambarkan jumlah hasil, biaya dan laba / rugi perusahaan pada suatu periode tertentu.

3. Laporan Perubahan Posisi Keuangan yang memuat sumber dan pengeluaran perusahaan selama satu periode.

4. Laporan Arus Kas yang menggambarkan sumber dan penggunaan kas dalam satu periode.

5. Laporan Harga Pokok Produksi menggambarkan berapa dan unsur apa yang diperhitungkan dalam harga pokok produksi suatu barang.

6. Laporan Laba Ditahan menjelaskan posisi laba yang tidak dibagikan kepada pemilik saham.

7. Laporan Perubahan Modal menjelaskan perubahan posisi modal.

Menurut pengertian dari beberapa ahli, analisa laporan keuangan menguraikan pospos keuangan menjadi unit informasi yang lebih kecil dan melihat hubungannya yang bersifat signifikan atau yang mempunyai makna antara satu dengan yang lain baik antara data kuantitatif maupun data non kuantitatif dengan tujuan untuk mengetahui kondisi keuangan lebih dalam yang sangat penting dalam proses menghasilkan keputusan yang tepat. Salah satu cara yang dapat digunakan adalah menggunakan analisa rasio, Sundjaja, Barlian, Sundjaja (2013:171) menyatakan bahwa: "Analisa rasio, adalah suatu metode perhitungan dan interpretasi rasio keuangan untuk menilai kinerja dan status suatu perusahaan".

Gitman dan Zutter (2015:119) menyatakan bahwa likuiditas merupakan kemampuan perusahaan untuk melunasi 
kewajiban jangka pendeknya ketika jatuh tempo. Maka dari itu, rasio likuiditas ditujukan untuk mengetahui kemampuan perusahaan dalam memenuhi kewajiban jangka pendek. Lebih lanjut Gitman dan Zutter (2015:121) menyatakan rasio aktivitas merupakan suatu pengukuran kecepatan berbagai akun untuk menjadi penjualan / kas, ataupun pemasukan (inflows) atau pengeluaran (outflows). Rasio utang yang mengukur besarnya total aktiva yang dibiayai oleh kreditur perusahaan; dengan kata lain mengukur berapa total aktiva yang dibiayai oleh hutang perusahaan.Terdapat tiga rasio profitabilitas yang umum digunakan, yakni:

- Marjin laba kotor: persentase hasil penjualan perusahaan yang telah dikurangi dengan harga pokok penjualan. Semakin tinggi marjin laba kotor, semakin baik penilaian terhadap perusahaan dan mengindikasikan harga pokok yang rendah.

- Marjin laba operasi: mengukur laba yang dihasilkan dari operasional perusahaan tanpa melibatkan beban bunga dan pajak. Perhitungan ini didapat dari pembagian antara laba sebelum bunga dan pajak dengan penjualan.

- Marjin laba bersih: mengukur laba yang dihasilkan ketika penjualan sudah dikurangi dengan beban bunga dan pajak.

Rasio pasar berhubungan dengan nilai pasar dari saham perusahaan. Rasio ini memberi informasi bagi investor mengenai seberapa baik perusahaan dalam mengelola hasil dan risiko.

\section{Piutang}

Leach dan Melicher (2015:124), menyatakan bahwa: "Accounts receivables are credits sales made to customers. That is, they are sales not requiring immediate cash payment but, rather, payment by a specified future date." Lebih lanjut, Weygandt, Warfield, dan Kieso (2015:384), menyatakan bahwa: "Receivables are claims held against customers and others for money, goods or services."

Piutang merupakan suatu bentuk transaksi yang mana penagihannya (claim) ditujukan pada konsumen atas produk baik berupa barang maupun jasa yang telah diterimanya Pada neraca, piutang digolongkan sebagai salah satu bentuk penerimaan perusahaan.

Pada umumnya, jenis-jenis piutang meliputi piutang usaha yang nilainya timbul sebagai bentuk dari penjualan barang atau jasa yang dilakukan secara kredit, wesel tagih yang merupakan surat hutang formal sebagai pendukung pengakuan hutang, dan piutang lain-lain selain daripada piutang dagang. Weygandt, Warfield, dan Kieso (2015) menyatakan pada umumnya, piutang usaha perusahaan dapat dikumpulkan dalam waktu 30 hingga 60 hari, sedangkan untuk wesel tagih, membutuhkan waktu yang lebih lama dalam penagihannya, yakni 60 hingga 90 hari dari hari transaksi. Lebih lanjut Weygandt, Warfield, dan Kieso (2015:384), mengkategorikan piutang menjadi beberapa bentuk, diantaranya:

"Receivables frequently classified as (1) account receivables, (2) notes receivable, and (3) other receivables. Account recivable are amounts owed by costumers on account. They result from the sales of goods and services. Notes receivable are claims for which formal instruments of credit are issued as proof of the debt. Other receivables include non-trade receivables. Examples are interest receivable, loans to company officers, advances employees, and income taxes refundable."

\section{Manajemen Piutang}

Jumlah piutang yang beredar setidaknya ditentukan oleh dua faktor, pertama adalah jumlah penjualan kredit dan kedua adalah rata-rata lamanya waktu penagihan. Risiko yang timbul dari penjualan yang dilakukan secaara kredit adalah timbulnya piutang 
tidak tertagih akibat keterlambatan pembayaran piutang. Pemberian kredit kepada pelanggan merupakan suatu bentuk investasi yang memerlukan pendanaan baik berupa tambahan dana ataupun tambahan biaya terkait. Gitman dan Zutter (2015:669), menyatakan bahwa:

"The objective for managing account receivables is to collect account receivables as quickly as possible without lossing sales from highpressure collection techniques. Accomplishing this goal encompasess three topics: (1) credit selection and standards (2) credit terms (3) credit monitoring.

Sundjaja, Barlian, Sundjaja (2013) menyatakan bahwa pengawasan piutang sangat penting untuk dilakukan. Tanpa adanya pengawasan, piutang mencapai tingkat yang berlebihan yang dapat menyebabkan arus kas menurun. Maka dari itu, tujuan manajemen piutang adalah untuk mendapatkan pembayaran atas piutang secepat mungkin tanpa kehilangan penjualan. Manajemen piutang dilaksanakan atas dasar rasio aktivitas yang terutama dilihat dari perputaran piutang dan rata-rata periode tagih.

Menurut Sundjaja, Barlian, Sundjaja (2013), manajemen piutang dimulai dengan membuat keputusan pemberian kredit. Seleksi pemberian kredit merupakan suatu keputusan dimana seseorang/perusahaan akan melakukan seleksi kepada pelanggannya dan menentukan berapa besar kredit yang akan diberikan. Tidak berhenti sampai kebijakan kredit, manajemen piutang akan melanjutkannya dengan kebijakan penagihan suatu pendekatan yang dilakukan oleh perusahaan dalam mengelola setiap aspek penagihan piutang usaha yang sangat dipengaruhi oleh kondisi persaingan. Lebih lanjut, Gitman dan Zutter (2015:669), menyatakan bahwa:

"Credit selection involves application of techniques for determining which customers should receive credit. This process involves evaluating the customer's creditworthiness and comparing it to firm's credit standards, its minimum requirements for extending credit to a customer."

Menurut Sundjaja, Barlian, Sundjaja (2013:376), dalam mengevaluasi berbagai permohonan kredit atau dalam menentukan kebijakan piutang, pengaruh kebijakan piutang yang utama terlihat pada laba perusahaan. Standar kredit adalah persyaratan minimum dalam memberikan kredit dan harus dipenuhi oleh pelanggan yang melakukan pembelian secara kredit.

Lebih lanjut Sundjaja, Barlian, Sundjaja (2013) menyatakan persyaratan/standar kredit merupakan syarat pembayaran yang dibutuhkan bagi peminjam. Misalnya syarat kredit dinyatakan seperti $2 / 10$ net 30 yang artinya pembeli menerima potongan sebesar $2 \%$ dan pembayaran paling lambat dilakukan dalam waktu 10 hari setelah awal periode kredit. Tetapi jika pelanggan tidak mengambil diskon tunai, maka keseluruhan pembayaran harus dilakukan dalam waktu 30 hari setelah awal periode kredit.

Persyaratan kredit terdiri dari 3 hal yaitu: (1) Diskon tunai, merupakan persentase pengurangan total yang dibayarkan konsumen apabila melakukan pembayaran kredit dalam waktu yang telah ditentukan terlebih dahulu. (2) Periode diskon tunai, menurut Gitman dan Zutter (2015:675), "Cash discount period is the number of days after the beginning of the credit period during which the cash discount is available." (3) Periode kredit.

\section{Metode Penelitian}

Metode penelitian yang digunakan dalam penelitian ini adalah metode descriptive study. Menurut Sekaran dan Bougie (2013:97), Descriptive study adalah suatu metode penelitian untuk mendeskripsikan karakteristik orang, kejadian, atau situasi. Dalam penelitian ini, objek penelitian yang dimaksud adalah CV.Y. 
Selain itu, penelitian juga termasuk ke dalam applied research. Menurut Sekaran dan Bougie (2013:5), applied research merupakan suatu penelitian yang ditujukan untuk memberikan suatu solusi terhadap masalah yang dialami oleh perusahaan

\section{Data Penelitian}

Data yang digunakan dalam penelitian ini dibagi ke dalam dua jenis, yaitu:

\section{Data primer}

Menurut Sekaran dan Bougie (2013:36), data primer adalah informasi yang peneliti cari, peroleh, dan catat sendiri baik melalui survey, wawancara, dan observasi terhadap objek yang diteliti. Cara-cara yang dilakukan oleh peneliti untuk memperoleh data primer adalah dengan melakukan wawancara kepada narasumber, dan pengumpulan dokumen keuangan CV.Y. Dengan melakukan wawancara, peneliti dapat memperoleh informasi seputar sejarah, profil, struktur organisasi, kebijakan penjualan kredit, serta kebijakan penagihan piutang. Melalui pengumpulan dokumen keuangan, dokumen tersebutdiolah menjadi perhitungan rasio keuangan, pengolahan laporan keuangan dalam bentuk common size,laporan arus kas, serta simulasi perubahan persyaratan kredit terhadap laba.

\section{Data sekunder}

Menurut Sekaran dan Bougie (2013:115), data sekunder merupakan data yang tidak diperoleh secara langsung oleh peneliti, melainkan merupakan data yang berasal dari sumber yang sudah tersedia di lapangan. Untuk memperoleh data sekunder yang nantinya digunakan untuk mendukung data primer, peneliti meminta dokumendokumen perusahaan seperti laporan laba rugi dan neraca selama 5 tahun terakhir, perhitungan angka kredit, laporan penjualan selama 5 tahun terakhir.

\section{Metode Analisis Data}

Teknik pengolahan data yang digunakan oleh peneliti adalah Analisis Kuantitatif. Menurut Sekaran dan Bougie (2013:3), data kuantitatif merupakan data yang berupa angka. Analisis atas data angka tersebut ditujukan untuk membandingkan besarnya perubahan pada laba yang diterima oleh CV.Y apabila melakukan perubahan kebijakan persyaratan kredit. Analisa didasarkan pada hasil wawancara dan laporan keuangan yangdidapatkan selama 5 tahun terakhir, dimulai dari Januari 2013 hingga bulan Desember 2017.

Untuk mengetahui perubahan laba yang diperoleh oleh CV. Y, perlu dilakukan beberapa perhitungan untuk setiap syarat kredit. Setiap syarat kredit memiliki perubahan tersendiri bagi perusahaan. Hal ini sejalan dengan pendapat Sundjaja, dkk dalam Manajemen Keuangan I (2013:377), yang menyatakan dalam mengevaluasi kebijakan-kebijakan kredit, beberapa variabel perlu diperhatikan, diantaranya:

- Volume penjualan (unit) atau hasil penjualan (Rupiah).

- Biaya piutang ragu-ragu. Risiko piutang ragu-ragu akan meningkat jika standar kredit diperlonggar.

- Investasi pada piutang.

- Harga pokok penjualan.

- Biaya administrasi. Biaya yang berhubungan dengan transaksi penjualan, pencatatan penjualan, piutang dan urusan administrasi lainnya.

- Biaya penagihan.

- Biaya diskon.

- Biaya kesempatan. Biaya yang berhubungan dengan peningkatan hasil tanpa adanya piutang ataupun peningkatan biaya karena terdapatnya piutang.

Setiap periode kredit menghasilkan nilai penjualan yang berbeda. Adapun nilai penjualan untuk setiap periode kredit dihitung dengan:

Nilai Penjualan Tahun Bersangkutan + Proyeksi Kenaikan Nilai Penjualan Perhitungan yang sama digunakan untuk menghitung perubahan Harga Pokok Penjualan untuk setiap periode kredit. 
Setiap peningkatan penjualan diiringi dengan peningkatan harga pokok penjualan.

Nilai HPP Tahun Bersangkutan

+ Proyeksi Kenaikan Nilai HPP

Semakin longgar suatu periode kredit, semakin tinggi risiko piutang tidak tertagih atau yang dikenal dengan piutang raguragu. Nilai piutang ragu-ragu di dasarkan pada nilai penjualan kredit, sehingga perhitungan dilakukan dengan rumus:

Penjualan Kredit

+ Proyeksi Presentasi Piutang Ragu

- Ragu

Dengan adanya penjualan kredit, Perusahaan perlu memastikan setiap administrasi berjalan dengan baik. Administrasi yang dimaksudkan adalah segala bentuk biaya untuk memastikan transaksi dan pencatatan berjalan dengan baik. Dalam penelitian ini, biaya administrasi juga termasuk biaya penagihan.

Piutang merupakan salah satu bentuk investasi. Setiap bentuk investasi memiliki suatu biaya yang dikenal dengan biaya kesempatan. Setiap perubahan pada piutang terlebih dahulu dilakukan pengklasifikasian dana. Dana bebas mengindikasikan bahwa perusahaan dapat menggunakan dana untuk menyimpannya dalam bentuk deposito yang akan menghasilkan penambahan hasil untuk setiap 1 Rupiahnya. Setiap klasifikasi dana bebas, menambah penghasilan sebesar persentase biaya kesempatan. Perubahan diklasifikasikan dana bebas ketika nilai piutang dagang saat ini lebih besar dari nilai piutang dagang atas periode kredit yang disimulasikan. Perhitungan biaya kesempatan dihitung dengan menggunakan rumus:

Perubahan Piutang Dagang

$\times$ Proyeksi Persentase Biaya Kesempatan

\section{Penjualan Kredit Tahun 2013 hingga Tahun 2017}

Gambar 1 (hlm 2) menunjukkan bahwa penjualan yang dilakukan oleh perusahaan bertitik berat pada penjualan secara kredit. Rata-rata persentase penjualan kredit sebesar $90 \%$ dari nilai penjualan.

\section{Piutang Dagang Tahun 2013 hingga} Tahun 2017

Gambar 4 menunjukkan bahwa selama 5 tahun terakhir, piutang belum tertagih (piutang ragu-ragu) perusahaan sempat mencapai $50 \%$ dari total penjualan kredit yakni pada tahun 2014, meskipun angka tersebut berhasil diturunkan pada tahun 2015 hingga tahun 2017. Piutang yang tidak dikelola dengan baik dapat menyebabkan pengurangan laba yang diperoleh oleh perusahaan.

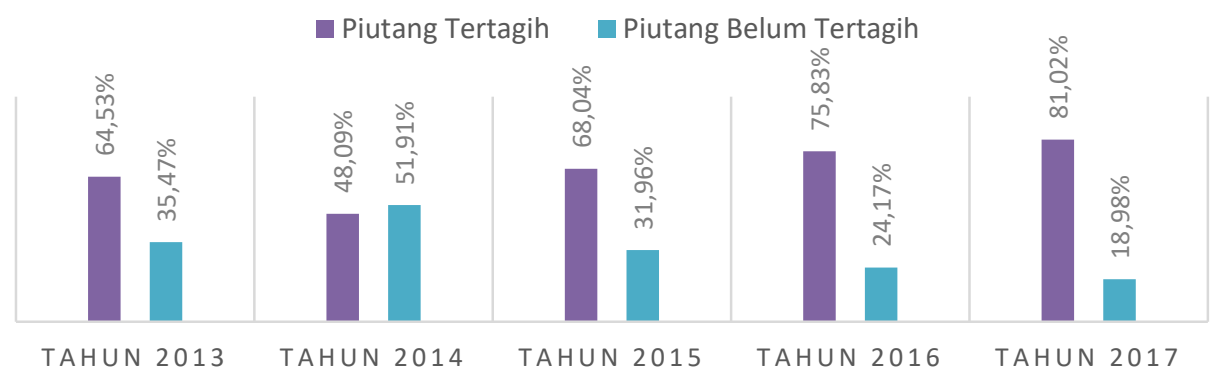

Gambar 4

Piutang Tertagih dan Tidak Tertagih

Sumber: Data Keuangan CV.Y 
Kondisi penagihan piutang dagang juga dapat dilihat dari rata-rata periode tagih yang ditunjukan pada rasio aktivitas. Gitman dan Zutter (2015) mengatakan bahwa rasio aktivitas merupakan salah satu bentuk alat yang mengukur seberapa cepat beberapa akun (kegiatan) menjadi suatu penjualan ataupun kas.

\section{Tabel 1}

Rasio Aktivitas

\begin{tabular}{|l|c|c|c|c|c|}
\hline Rasio & 2013 & 2014 & 2015 & 2016 & 2017 \\
\hline $\begin{array}{l}\text { Perputaran } \\
\text { Persediagn }\end{array}$ & 8,856 & 81,748 & 107,984 & 12,252 & 14,432 \\
\hline $\begin{array}{l}\text { Perputaran } \\
\text { Total } \\
\text { Aktiva }\end{array}$ & 1,989 & 1,949 & 2,475 & 2,801 & 3,210 \\
\hline $\begin{array}{l}\text { Rata-Rata } \\
\text { Periode } \\
\text { Bayar }\end{array}$ & 103,625 & 89,771 & 71,276 & 40,108 & 32,619 \\
\hline $\begin{array}{l}\text { Rasa-Rata } \\
\text { Periode } \\
\text { Tagih }\end{array}$ & 116,518 & 170,532 & 104,979 & 79,400 & 62,364 \\
\hline
\end{tabular}

\section{Sumber: data keuangan yang telah diolah}

Perputaran persediaan dan total aktiva menunjukkan seberapa cepat persediaan maupun aktiva lainnya dapat terjual. Hasil perhitungan menunjukkan selama 5 periode terakhir (terhitung dari tahun 2013 - 2017), CV.Y mengalami peningkatan perputaran aktiva. Sedangkan untuk rata-rata periode pembayaran, selama 5 periode tersebut Perusahaan mengalami penurunan. Hal ini menunjukkan dari tahun 2013 hingga tahun 2017, pembayaran atas pembelian yang dilakukan CV.Y semakin cepat.

Rata-rata periode tagih menunjukkan seberapa cepat perusahaan dapat mendapatkan pelunasan atas piutangnya, yang mana selama 5 periode terakhir Perusahaan mengalami waktu pelunasan piutang yang cukup lama. Dikatakan cukup lama karena rata-rata periode tagih Perusahaan adalah 107 hari, jauh melebihi rata-rata periode tagih industri yakni 45 hari. Pada awal Tahun 2015, perusahaan mulai menerapkan manajemen piutang, berupa penetapan periode kredit selama 30 hari; batas paling lambat piutang tertagih. Namun pada pelaksanaannya, lamanya piutang tertagih melebihi waktu yang ditetapkan.

\section{Manajemen Piutang CV.Y}

Pada awal tahun 2015, Perusahaan mulai menerapkan manajemen piutang dalam pembentuk seleksi pemberian kredit $(5 \mathrm{~K})$ yang menghasilkan nilai kredit atau yang biasa disebut dengan 5K. Dalam penjualan kreditnya, CV.Y tidak menerapkan seluruh 5K, seleksi yang dilakukan Perusahaan diantaranya:

- Karakter.

Sebelum melakukan penjualan kredit, konsumen diminta untuk mengisi suatu formulir identitas.

- Kemampuan.

CV.Y mewajibkan konsumen untuk mengikuti masa "percobaan", dimana konsumen diminta melakukan transaksi tunai selama 3 bulan.

- Kapital.

CV.Y mewajibkan konsumen untuk melampirkan laporan keuangan untuk beberapa periode .

Selain dengan seleksi pemberian kredit, CV.Y juga menetapkan periode kredit yakni $\mathrm{n} / 30$. Hal tersebut menunjukkan pelunasan pejualan kredit maksimal dilakukan 30 hari setelah transaksi dilakukan. Namun, dalam pelaksanaannya, rata-rata pelunasan piutang lebih dari 30 hari, dimana rata-rata penagihan perusahaan berada pada kisaran 60 hingga 100 hari. Rata-rata periode tagih juga melampaui rata-rata secara industri yang hanya selama 45 hari. Tabel 2 menunjukkan bahwa standar kredit yang dilakukan perusahaan terlalu longgar.

\section{Tabel 2}

Piutang Tertagih dan Tidak Tertagih Tahun 2015 - Tahun 2017

\begin{tabular}{|c|c|c|c|}
\hline & $\begin{array}{c}\text { Tahun } \\
\mathbf{2 0 1 5}\end{array}$ & $\begin{array}{c}\text { Tahun } \\
\mathbf{2 0 1 6}\end{array}$ & $\begin{array}{c}\text { Tahun } \\
\mathbf{2 0 1 7}\end{array}$ \\
\hline $\begin{array}{c}\text { Piutang } \\
\text { Tertagih }\end{array}$ & $68,04 \%$ & $75,83 \%$ & $81,02 \%$ \\
\hline $\begin{array}{c}\text { Piutang Tidak } \\
\text { Tertagih }\end{array}$ & $31,96 \%$ & $24,17 \%$ & $18,98 \%$ \\
\hline
\end{tabular}

Sumber: Dokumen Keuangan 


\section{Hasil Penelitian dan Pembahasan}

Pengaruh Piutang Dagang Terhadap Laporan Keuangan

\section{A. Pengaruh Piutang Dagang Terhadap Laba Rugi}

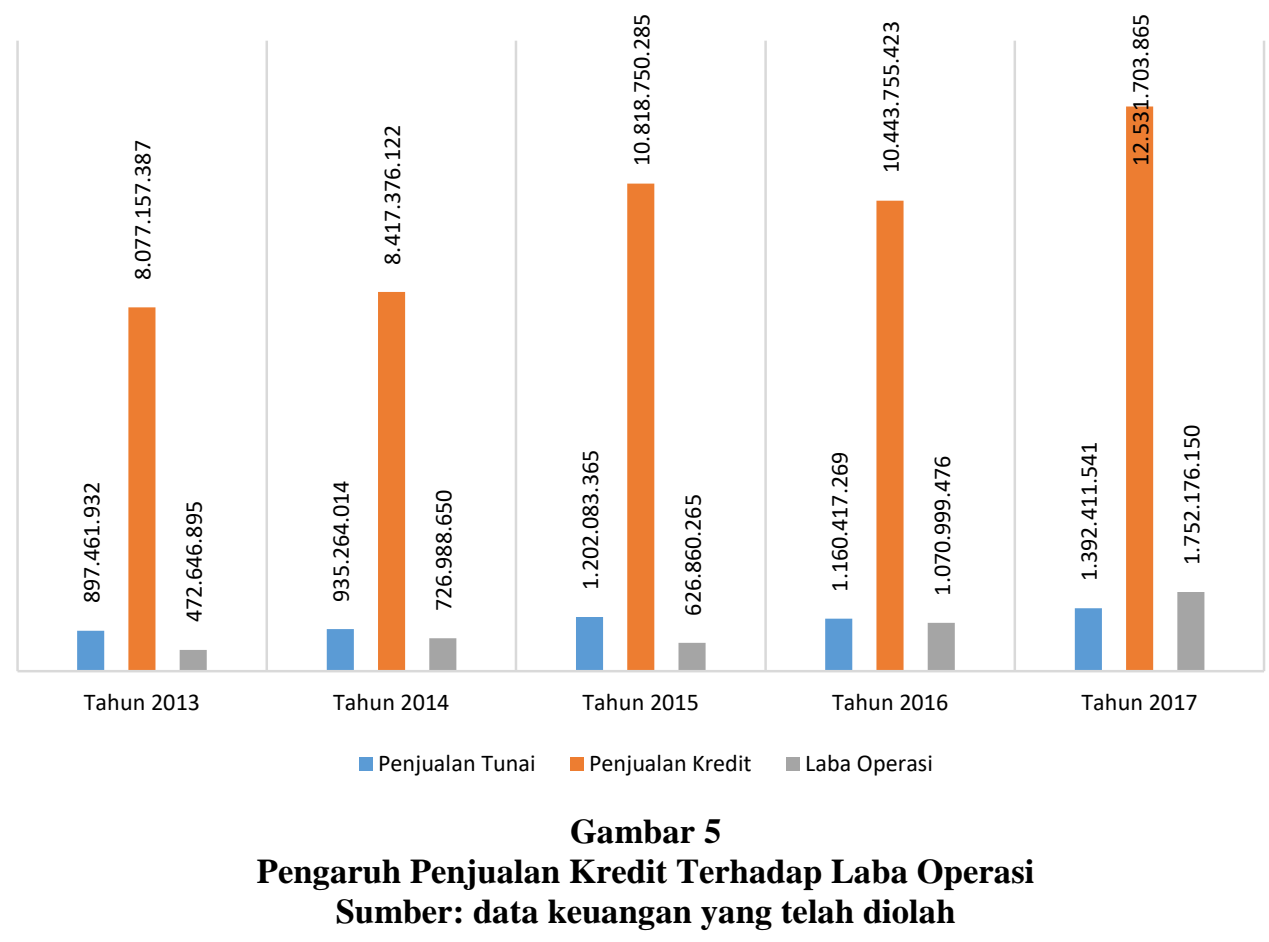

Gambar 5 menggambarkan suatu kondisi perusahaan terkait laba operasional yang diperolehnya atas hasil penjualan, dimana $90 \%$ hasil penjualan dilakukan secara kredit. Kedua hal tersebut menunjukkan hubungan yang saling menguntungkan, dimana kenaikan 1 Rupiah penjualan kredit meningkatkan laba operasional; sebagai salah satu cerminan dari laba bersih yang ditimbulkan. Laba operasional tersebut juga dipengaruhi oleh unsur lain yang berpengaruh negatif; seperti total Harga Pokok Penjualan.

Salah satu alat untuk melakukan evaluasi keuntungan terhadap penjualan adalah melalui laporan laba rugi common size, yang dibuat dalam bentuk persentase terhadap nilai penjualan. Tabel 3 menunjukkan laporan laba rugi CV.Y dalam bentuk common size selama tahun 2013 hingga tahun 2017. 
Tabel 3

Laporan Laba Rugi Common Size

\begin{tabular}{|c|c|c|c|c|c|}
\hline \multicolumn{6}{|c|}{ CV. Y } \\
\hline \multicolumn{6}{|c|}{ Rekapitulasi Laporan Laba Rugi Common Size } \\
\hline \multicolumn{6}{|c|}{ (dalam persentase) } \\
\hline & $\begin{array}{l}\text { Tahun } \\
2013 \\
\end{array}$ & $\begin{array}{c}\text { Tahun } \\
2014\end{array}$ & $\begin{array}{c}\text { Tahun } \\
2015\end{array}$ & $\begin{array}{c}\text { Tahun } \\
2016\end{array}$ & Tahun 2017 \\
\hline \multicolumn{6}{|c|}{ PENDAPATAN USAHA } \\
\hline Penjualan Tunai & $10,000 \%$ & $10,000 \%$ & $10,000 \%$ & $10,000 \%$ & $10,000 \%$ \\
\hline Penjualan Kredit & $90,000 \%$ & $90,000 \%$ & $90,000 \%$ & $90,000 \%$ & $90,000 \%$ \\
\hline $\begin{array}{l}\text { PENDAPATAN } \\
\text { USAHA }\end{array}$ & $100,000 \%$ & $100,000 \%$ & $100,000 \%$ & $100,000 \%$ & $100,000 \%$ \\
\hline \multicolumn{6}{|c|}{ HARGA POKOK PENJUALAN } \\
\hline Persediaan Awal & $10,869 \%$ & $10,265 \%$ & $0,878 \%$ & $8,343 \%$ & $6,174 \%$ \\
\hline Pembelian & $94,561 \%$ & $83,090 \%$ & $94,785 \%$ & $89,836 \%$ & $87,299 \%$ \\
\hline Persediaan Akhir & $10,697 \%$ & $1,128 \%$ & $0,878 \%$ & $7,409 \%$ & $6,057 \%$ \\
\hline $\begin{array}{c}\text { TOTAL HARGA } \\
\text { POKOK } \\
\text { PENJUALAN } \\
\end{array}$ & $94,734 \%$ & $92,227 \%$ & $\mathbf{9 4 , 7 8 5 \%}$ & $\mathbf{9 0 , 7 7 1 \%}$ & $87,416 \%$ \\
\hline LABA OPERASI & $5,266 \%$ & $7,773 \%$ & $5,215 \%$ & $9,229 \%$ & $12,584 \%$ \\
\hline
\end{tabular}

Sumber: data keuangan yang telah diolah

Seiring dengan peningkatan nilai penjualan, CV.Y juga mengalami peningkatan laba operasional. Rata-rata peningkatan laba operasional perusahaan adalah $1,8 \%$. Peningkatan tersebut diiringi dengan peningkatan rata-rata penjualan sebesar Rp. 1.237.374.022,00/tahun yang terdiri dari rata-rata peningkatan penjualan kredit sebesar Rp. 1.113.636.620,00/tahun.

\section{B. Pengaruh Piutang Dagang Terhadap Neraca}

Neraca, suatu laporan keuangan yang menunjukkan posisi keuangan perusahaan pada tanggal pembuatannya (Sundjaja, dkk, 2013). Laporan ini menunjukkan keseimbangan atas apa yang dimiliki oleh perusahaan; asset; dengan cara pembiayaannya; baik berupa modal sendiri maupun melalui kegiatan perhutangan (Gitman dan Zutter, 2015). Salah satu komponen dari laporan ini adalah current assets atau yang dikenal dengan aset lancar; beberapa bentuk kekayaan perusahaan yang diharapkan dalam jangka waktu kurang dari 1 tahun berbentuk tunai; misalnya piutang dagang. Piutang dagang merupakan suatu bentuk transaksi yang mana penagihannya (claim) ditujukan pada konsumen atas produk baik berupa barang maupun jasa yang telah diterimanya (Weygandt, dkk, 2015); bentuk aset ini timbul atas penjualan kredit yang dilakukan oleh perusahaan. 


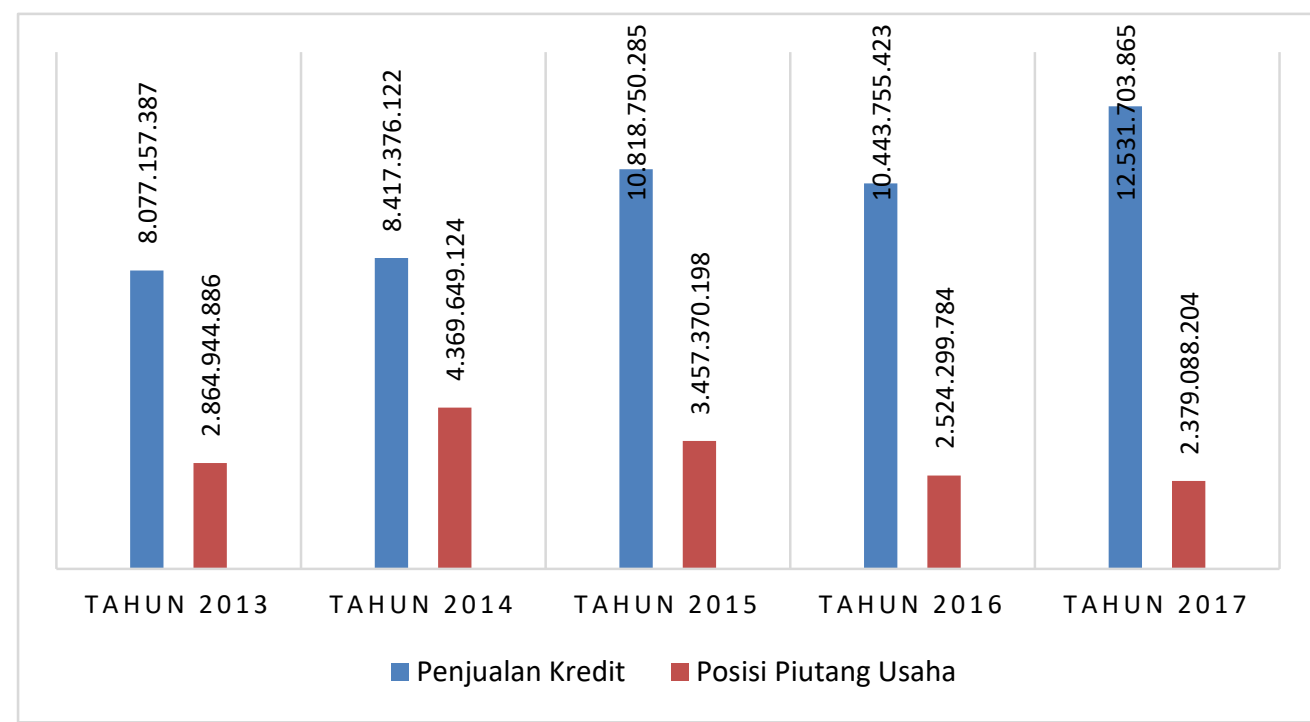

\section{Gambar 6 \\ Penjualan Kredit dengan Piutang Usaha CV. Y Sumber: data keuangan yang telah diolah}

Gambar 6 menunjukkan bahwa piutang usaha perusahaan dapat dikatakan mengalami penurunan selama 5 tahun terakhir (tahun 2013 hingga tahun 2017), dengan penurunan terbesar pada tahun 2015 dan 2016. Secara umum hubungan antar penjualan kredit dengan piutang usaha merupakan hubungan yang positif. Hubungan yang positif dalam hal ini berarti kenaikan 1 Rupiah penjualan kredit mempengaruhi besarnya kenaikan piutang usaha.

Namun hubungan tersebut bukan merupakan hal yang konstan, terdapat faktor-faktor lain yang mempengaruhi nilai piutang usaha. Misalnya, cara mengelola penjualan kredit; tanpa adanya pengawasan penjualan kredit, nilai piutang usaha dapat terus melonjak meskipun tidak terdapat perubahan pada penjualan kredit. Sedangkan melalui pengawasan piutang hal sebaliknya terjadi, dimana penjualan kredit meningkat namun piutang menurun. Apabila tidak dikelola dengan baik semakin tinggi penjualan kredit, semakin tinggi pula indikasi piutang usaha tidak tertagih.

Gambar 6 menunjukkan bahwa CV.Y mengalami penurunan piutang meskipun terjadi peningkatan penjualan kredit, terutama semenjak tahun 2015. Hal inimenunjukkan bahwa manajemen piutang yang diterapkan oleh perusahaan telah berjalan dengan cukup baik dan telah memberikan kontribusinya dalam menjaga ataupun mengontrol penerimaan atas penjualan kredit yang dilakukannya. Hanya dalam pelaksanaannya, manajamen piutang tersebut kurang sesuai dengan kondisi industri. Hal ini dibuktikan dengan melebihinya rata-rata periode tagih CV.Y dibandingkan dengan rata-rata periode tagih secara industri.

\section{Pengaruh Piutang Dagang Terhadap Arus Kas \\ Disamping itu, meningkatnya piutang usaha mempengaruhi aliran kas bersih perusahaan, dengan nilai yang dapat lebih besar ataupun lebih kecil dari laba bersih yang tertera di Laporan Laba Rugi CV.Y.}


Tabel 4

Laporan Arus Kas

\begin{tabular}{|c|c|c|c|c|}
\hline \multicolumn{5}{|c|}{ CV.Y } \\
\hline \multicolumn{5}{|c|}{ Laporan Arus Kas } \\
\hline \multicolumn{5}{|c|}{ Per 31 Desember } \\
\hline \multicolumn{5}{|c|}{ (dalam Rupiah) } \\
\hline $\begin{array}{c}\text { Arus Kas dari } \\
\text { Aktivitas Operasi: }\end{array}$ & Tahun 2014 & Tahun 2015 & Tahun 2016 & Tahun 2017 \\
\hline $\begin{array}{c}\text { Laba Bersih Sesudah } \\
\text { Pajak }\end{array}$ & 189.642 .841 & 241.042 .086 & 243.816 .320 & 342.193 .593 \\
\hline Penyusutan & 15.663 .136 & 14.997 .528 & 13.573 .833 & 92.409 .251 \\
\hline $\begin{array}{c}\text { Peningkatan / } \\
\text { Penurunan Piutang } \\
\end{array}$ & $\begin{array}{c}(1.504 .704 .238 \\
)\end{array}$ & 912.278 .926 & 933.070 .414 & 145.211 .580 \\
\hline $\begin{array}{c}\text { Peningkatan / } \\
\text { Penurunan Persediaan }\end{array}$ & 854.500 .000 & - & (754.191.968) & 16.284 .026 \\
\hline $\begin{array}{c}\text { Peningkatan / } \\
\text { Penurunan Pajak } \\
\text { Dibayar Dimuka }\end{array}$ & 43.364 .282 & $(15.666 .332)$ & $(20.056 .984)$ & $(5.547 .653)$ \\
\hline $\begin{array}{c}\text { Peningkatan / } \\
\text { Penurunan Piutang } \\
\text { Lainnya } \\
\end{array}$ & 371.140 .462 & - & - & - \\
\hline $\begin{array}{c}\text { Peningkatan / } \\
\text { Penurunan Hutang } \\
\text { Usaha }\end{array}$ & 68.942 .165 & $\begin{array}{c}(181.519 .623 \\
)\end{array}$ & $\begin{array}{c}(1.052 .063 .496 \\
)\end{array}$ & $(8.329 .650)$ \\
\hline $\begin{array}{c}\text { Peningkatan / } \\
\text { Penurunan Hutang } \\
\text { Pajak } \\
\end{array}$ & 24.865 .462 & 1.918 .319 & $(6.058 .918)$ & $(38.625 .104)$ \\
\hline $\begin{array}{c}\text { Peningkatan / } \\
\text { Penurunan Hutang } \\
\text { Lain } \\
\end{array}$ & 4.050 .000 & $(4.050 .000)$ & 100.000 .000 & $(100.000 .000)$ \\
\hline $\begin{array}{c}\text { Kas yang Diperoleh } \\
\text { dari Aktivitas } \\
\text { Operasi }\end{array}$ & 67.464.110 & 969.000 .904 & (541.910.799) & 443.596.043 \\
\hline $\begin{array}{c}\text { Arus Kas dari } \\
\text { Aktivitas Investasi: }\end{array}$ & Tahun 2014 & Tahun 2015 & Tahun 2016 & Tahun 2017 \\
\hline $\begin{array}{c}\text { Pembelian / Penjualan } \\
\text { Peralatan }\end{array}$ & $(9.501 .000)$ & $(2.850 .000)$ & $(6.445 .000)$ & 16.127 .083 \\
\hline $\begin{array}{c}\text { Pembelian / Penjualan } \\
\text { Kendaraan }\end{array}$ & $(28.600 .000)$ & - & $(581.000 .000)$ & $(16.127 .083)$ \\
\hline $\begin{array}{c}\text { Kas yang Diperoleh } \\
\text { dari Aktivitas } \\
\text { Investasi } \\
\end{array}$ & (38.101.000) & $(2.850 .000)$ & $(587.445 .000)$ & - \\
\hline $\begin{array}{c}\text { Arus Kas dari } \\
\text { Aktivitas Pendanaan: }\end{array}$ & Tahun 2014 & Tahun 2015 & Tahun 2016 & Tahun 2017 \\
\hline $\begin{array}{c}\text { Perubahan Hutang } \\
\text { Jangka Panjang }\end{array}$ & - & - & - & - \\
\hline
\end{tabular}

Sumber: data keuangan yang telah diolah 
Tabel 4 (Lanjutan)

Laporan Arus Kas

\begin{tabular}{|c|c|c|c|c|}
\hline $\begin{array}{c}\text { Perubahan Modal } \\
\text { Pemegang Saham }\end{array}$ & - & - & - & - \\
\hline $\begin{array}{c}\text { Kas yang Diperoleh } \\
\text { dari Aktivitas } \\
\text { Pendanaan }\end{array}$ & - & - & - & - \\
\hline $\begin{array}{c}\text { Kenaikan Bersih } \\
\text { dalam Kas dan Bank }\end{array}$ & $\mathbf{2 9 . 3 6 3 . 1 1 0}$ & $\mathbf{9 6 6 . 1 5 0 . 9 0 4}$ & $\begin{array}{c}(\mathbf{1 . 1 2 9 . 3 5 5 . 7 9 9} \\
\text { ) }\end{array}$ & $\mathbf{4 4 3 . 5 9 6 . 0 4 3}$ \\
\hline
\end{tabular}

Sumber: data keuangan yang telah diolah

Tabel 4 menunjukkan kenaikan kas bersih CV.Y selama tahun 2013 hingga tahun 2017. Pada tahun 2014, Perusahaan mengalami kenaikan kas sebesar 29.363.110 dengan terdapat peningkatan piutang usaha sebesar 1.504.704.238. Sedangkan pada tahun 2015, meskipun CV.Y mengalami penurunan penjualan, Perusahaan tetap mengalami kenaikan kas sebesar 966.150.904. Hal ini ditandai dengan penurunan piutang usaha sebesar 912.278.926. Penurunan piutang usaha ini terus berlanjut sampai dengan tahun 2017.

Penurunan piutang usaha
meningkatkan kas bersih bagi
perusahaan. Penurunan penjualan disertai dengan penurunan piutang pada Tahun 2015 menunjukkan bahwa meskipun CV.Y mengalami penurunan penjualan, namun Perusahaan dapat menekan ataupun mengontrol penerimaan atas penjualan kredit yang dilakukannya.

\section{Simulasi Perubahan Syarat Kredit}

Persyaratan kredit merupakan syarat pembayaran yang dibutuhkan bagi peminjam. Umumnya terdapat 3 komponen utama dalam syarat kredit, yaitu: diskon tunai, periode diskon tunai, dan periode kredit. Misalnya syarat kredit dinyatakan dalam $2 / 10-n / 30$, hal ini berarti pembeli akan mendapatkan potongan sebesar $2 \%$ dengan pembayaran paling lambat dalam waktu 10 hari setelah awal periode kredit. Apabila pembeli tidak mengambil diskon tunai,

pembayaran yang harus dilakukannya adalah 30 hari setelah awal periode kredit

Tabel 5

Proyeksi Kenaikan Nilai Penjualan, HPP dan Biaya Piutang Ragu-Ragu

\begin{tabular}{|c|c|c|c|}
\hline $\begin{array}{c}\text { Periode } \\
\text { Kredit }\end{array}$ & $\begin{array}{c}\text { Kenaikan } \\
\text { Nilai } \\
\text { Penjualan }\end{array}$ & $\begin{array}{c}\text { Kenaikan } \\
\text { Nilai HPP }\end{array}$ & $\begin{array}{c}\text { Biaya } \\
\text { Piutang } \\
\text { Ragu- } \\
\text { Ragu }\end{array}$ \\
\hline $2 / 10-\mathrm{n} / 30$ & $10 \%$ & $5 \%$ & $2 \%$ \\
\hline $4 / 10-\mathrm{n} / 30$ & $12 \%$ & $6 \%$ & $2,5 \%$ \\
\hline $2 / 20-\mathrm{n} / 30$ & $14 \%$ & $7 \%$ & $3 \%$ \\
\hline $4 / 20-\mathrm{n} / 30$ & $16 \%$ & $8 \%$ & $3,5 \%$ \\
\hline $2 / 10-\mathrm{n} / 45$ & $20 \%$ & $10 \%$ & $4 \%$ \\
\hline
\end{tabular}

Sumber: data keuangan yang telah diolah

Proyeksi kenaikan nilai baik penjualan maupun HPP didasarkan pada suatu proporsi. Dimana setiap penambahan periode kredit, meningkatkan nilai penjualan sebesar $2 \%$, dan ketika periode kredit semakin diperlonggar, kenaikan penjualan di proyeksikan meningkat sebanyak $4 \%$ sehingga mencapai $20 \%$. Proporsi kenaikan HPP terhadap nilai penjualan adalah 1:2, sehingga kenaikan $1 \%$ akan meningkatkan nilai HPP sebesar $0,5 \%$. Proporsi piutang ragu-ragu terhadap penjualan adalah $1: 5$, sehingga kenaikan $1 \%$ penjualan akan meningkatkan biaya piutang ragu-ragu sebesar $0,2 \%$ dengan pembulatan ke atas menjadi $0,5 \%$. 
Tabel 6

Proyeksi RPT dan Pelanggan yang Mengambil Diskon untuk Setiap

Periode Kredit

\begin{tabular}{|c|c|c|}
\hline $\begin{array}{c}\text { Periode } \\
\text { Kredit }\end{array}$ & $\begin{array}{c}\text { RPT } \\
\text { (hari) }\end{array}$ & $\begin{array}{c}\text { Persentase Pelanggan } \\
\text { yang Mengambil } \\
\text { Diskon }\end{array}$ \\
\hline $2 / 10-\mathrm{n} / 30$ & 40 & $50 \%$ \\
\hline $4 / 10-\mathrm{n} / 30$ & 30 & $60 \%$ \\
\hline $2 / 20-\mathrm{n} / 30$ & 35 & $55 \%$ \\
\hline $4 / 20-\mathrm{n} / 30$ & 30 & $70 \%$ \\
\hline $2 / 10-\mathrm{n} / 45$ & 50 & $40 \%$ \\
\hline
\end{tabular}

Sumber: data keuangan yang telah diolah

Tabel 6 menunjukkan proyeksi RPT dan perkiraan pelanggan yang akan mengambil diskon. Semakin tinggi diskon dan semakin lama periode diskon diberikan, RPT menjadi semakin cepat, demikian pula dengan proyeksi pelanggan yang akan mengambil diskon tunai.

Tabel 7

Biaya Admin dan Biaya Kesempatan

\begin{tabular}{|c|c|c|}
\hline $\begin{array}{c}\text { Periode } \\
\text { Kredit }\end{array}$ & $\begin{array}{c}\text { Biaya Admin } \\
\text { / tahun }\end{array}$ & $\begin{array}{c}\text { Biaya } \\
\text { Kesem } \\
\text { patan }\end{array}$ \\
\hline $2 / 10-\mathrm{n} / 30$ & 600.000 & \multirow{1}{*}{$5 \%$} \\
\cline { 1 - 2 } $5 / 10-\mathrm{n} / 30$ & 600.000 & \\
\cline { 1 - 2 } $2 / 20-\mathrm{n} / 30$ & 660.000 & \\
\hline $4 / 20-\mathrm{n} / 30$ & 660.000 & \\
\hline $2 / 10-\mathrm{n} / 45$ & 720.000 & \\
\hline
\end{tabular}

Sumber: data keuangan yang telah diolah
Untuk periode diskon 10 hari dan periode kredit 30 hari, perusahaan memproyeksikan peningkatan sebesar $\mathrm{Rp}$ 50.000/bulan sehingga dalam satu tahun meningkat sebesar Rp 600.000,00. Biaya di proyeksikan meningkat seiring peningkatan periode diskon, menjadi $\mathrm{Rp}$ 55.000/bulan untuk periode diskon 20 hari sehingga dalam satu tahun meningkat sebesar Rp Rp 660.000,00. Periode kredit $\mathrm{n} / 45$ membutuhkan biaya administrasi terbesar yakni Rp 60.000/bulan, Rp 720.000,00 untuk satu tahunnya. Biaya kesempatan yang hilang terhitung dari selisih kenaikan piutang tanpa periode kredit dan dengan periode kredit, sebesar tingkat bunga simpanan bank BCA yakni 5\%. Simpanan dilakukan dalam bentuk deposito, kenaikan bunga deposito tidak dikenakan pajak karena tidak tergolong pada $\mathrm{PPh}$ 23.

\section{Dampak Penerapan Simulasi Perubahan Persyaratan Kredit Terhadap Laba Perusahaan}

Perhitungan simulasi periode kredit dihitung untuk setiap laporan keuangan laba rugi tahun 2013 hingga tahun 2017. Perhitungan perubahan pada keuntungan (laba) yang diperoleh menggunakan prinsip ceteris paribus dimana biaya maupun unsur lain selain yang terdapat pada Tabel 5 hingga Tabel 7, dianggap sama atau tidak mengalami perubahan. 
Jurnal Akuntansi Maranathaø Volume 11 Nomor 2, November 2019 :289-307

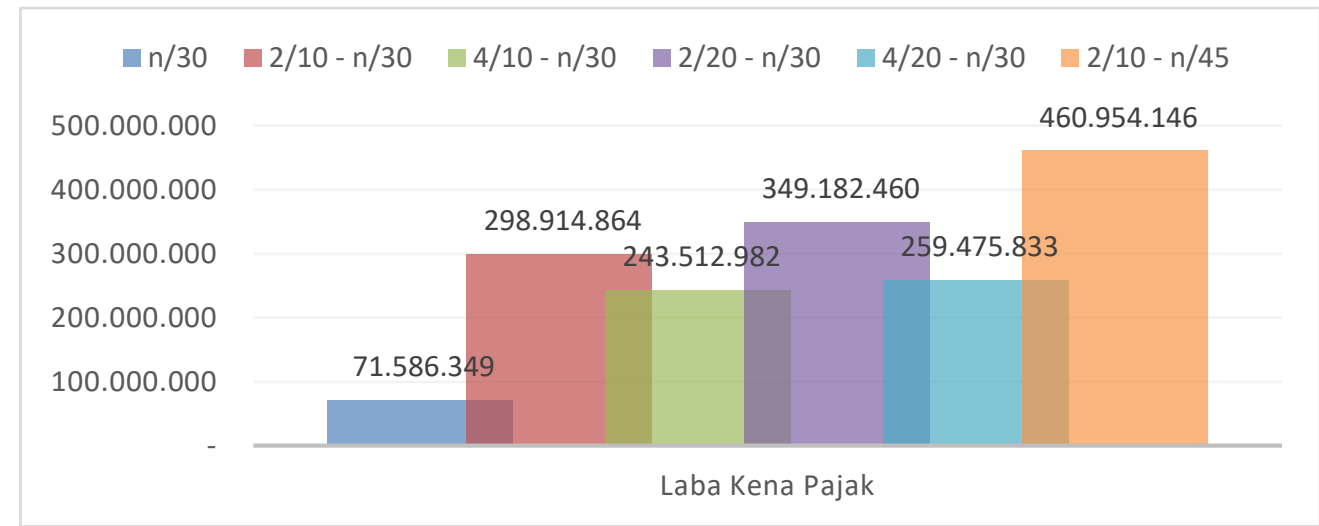

\section{Gambar 7}

Proyeksi Laba Tahun 2013

Sumber: data keuangan yang telah diolah

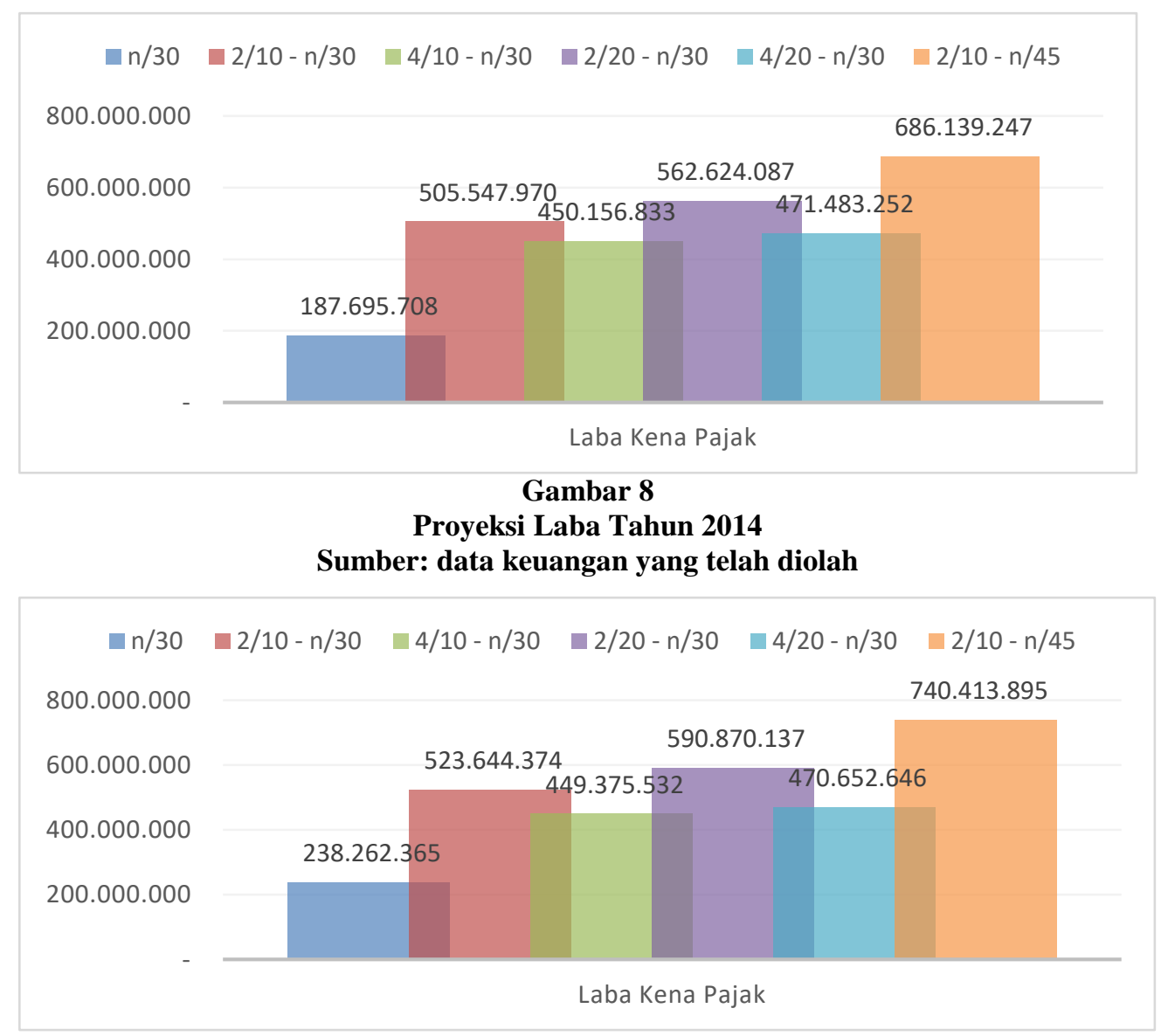

\section{Gambar 9}

Proyeksi Laba Tahun 2015

Sumber: data keuangan yang telah diolah 


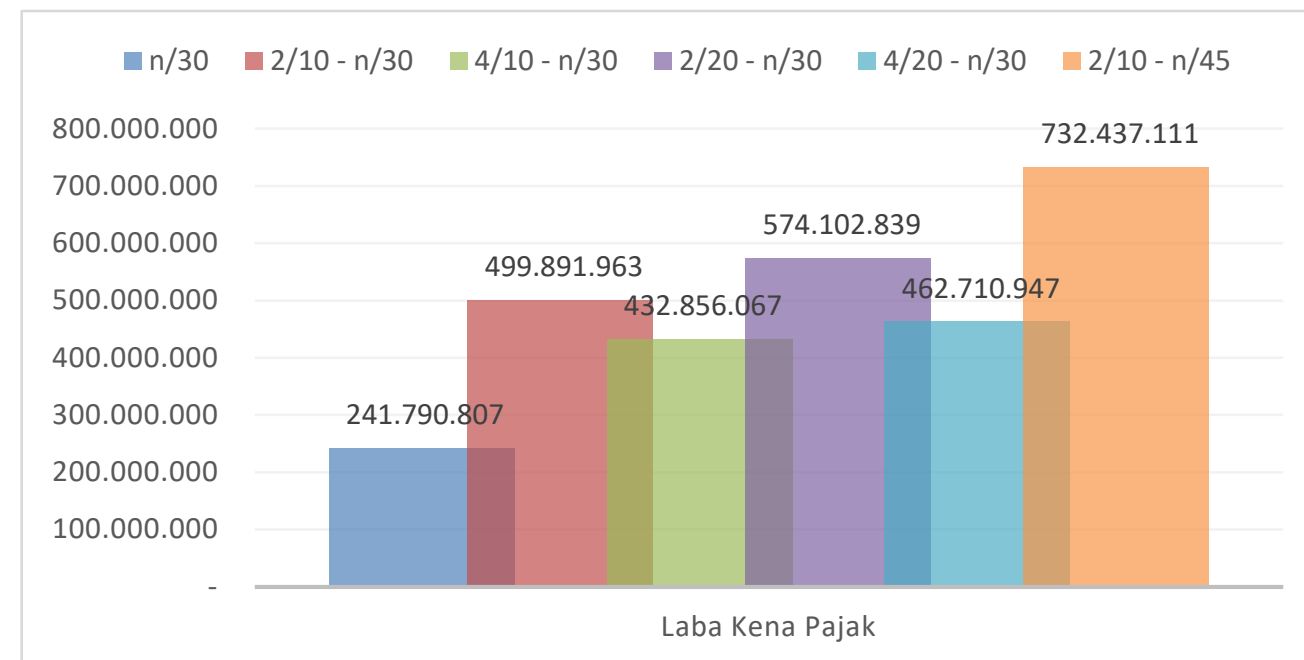

Gambar 10

Proyeksi Laba Tahun 2016

Sumber: data keuangan yang telah diolah

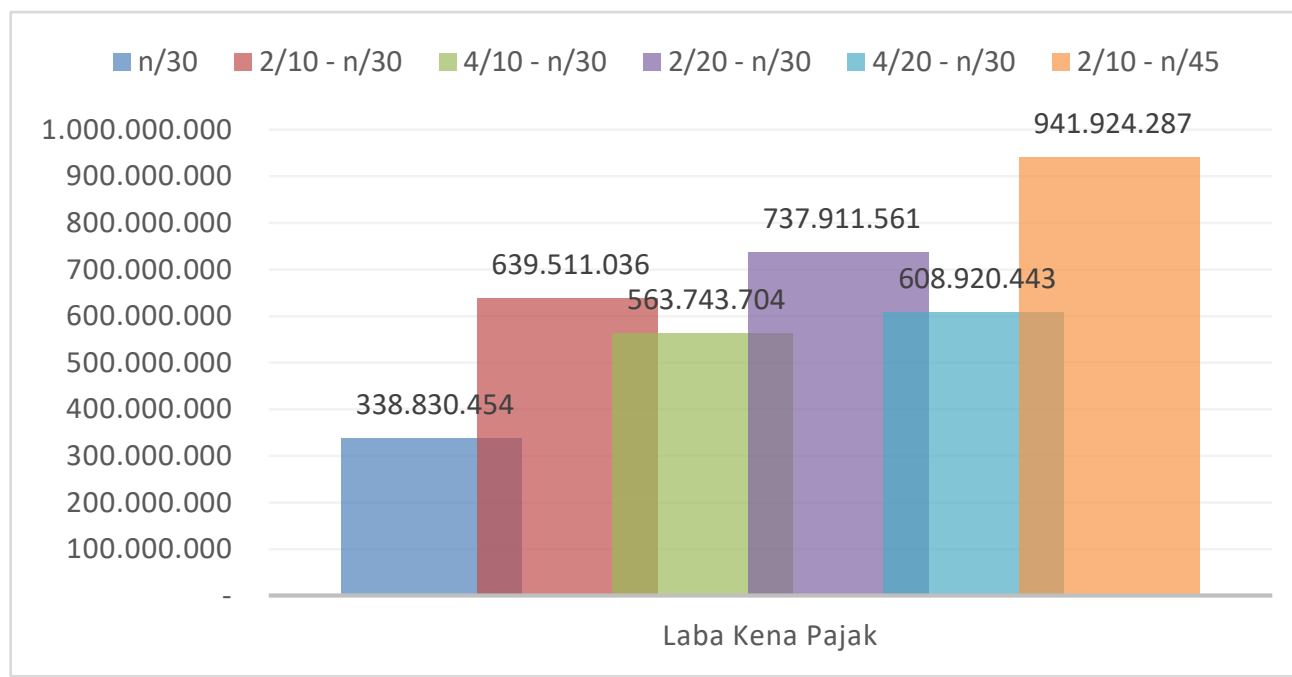

Gambar 11

Proyeksi Laba Tahun 2017

Sumber: data keuangan yang telah diolah

Proyeksi laba paling tinggi dihasilkan pada periode kredit 2/10 - n/45. Dimana batas paling lambat konsumen membayar adalah 45 hari dengan periode diskon tunai selama 10 hari dengan diskon 2\%. Melalui periode kredit tersebut, Perusahaan dapat meningkatkan penjualan kredit. Sedangkan pemberian diskon memberikan "rangsangan" bagi para konsumen untuk dapat membayar dalam kurun waktu 10 hari. Periode kredit disesuaikan dengan rata-rata periode tagih industri yakni 45 hari. Tabel 8 menunjukkan perbandingkan syarat kredit saat ini dan syarat kredit yang diajukan yakni $2 / 10-n / 45$. 
Tabel 8

Perbandingan Laba Kena Pajak Periode Kredit n/30 dan 2/10 - n/45

\begin{tabular}{|c|c|c|c|c|c|c|c|c|}
\hline & \multicolumn{3}{|c|}{ Syarat Kredit: n/30 } & \multicolumn{4}{|c|}{ Syarat Kredit: 2/10 - n/45 } \\
\cline { 2 - 8 } & $\begin{array}{c}\text { Periode } \\
\text { Diskon }\end{array}$ & $\begin{array}{c}\text { Periode } \\
\text { Kredit }\end{array}$ & Diskon & $\begin{array}{c}\text { Laba } \\
\text { Sebelum } \\
\text { Bunga dan } \\
\text { Pajak }\end{array}$ & $\begin{array}{c}\text { Periode } \\
\text { Diskon }\end{array}$ & $\begin{array}{c}\text { Periode } \\
\text { Kredit }\end{array}$ & $\begin{array}{c}\text { Diskon } \\
\text { Sebelum } \\
\text { Bunga dan } \\
\text { Pajak }\end{array}$ \\
\hline $\begin{array}{c}\text { Tahun } \\
2013\end{array}$ & - & 30 & - & 71.586 .349 & 10 & 45 & $2 \%$ & 619.831 .955 \\
\hline $\begin{array}{c}\text { Tahun } \\
2014\end{array}$ & - & 30 & - & 187.695 .708 & 10 & 45 & $2 \%$ & 851.709 .163 \\
\hline $\begin{array}{c}\text { Tahun } \\
2015\end{array}$ & - & 30 & - & 238.262 .365 & 10 & 45 & $2 \%$ & 953.218 .878 \\
\hline $\begin{array}{c}\text { Tahun } \\
2016\end{array}$ & - & 30 & - & 241.790 .807 & 10 & 45 & $2 \%$ & 937.865 .939 \\
\hline $\begin{array}{c}\text { Tahun } \\
2017\end{array}$ & - & 30 & - & 338.830 .454 & 10 & 45 & $2 \%$ & 1.188 .423 .093 \\
\hline
\end{tabular}

Sumber: Data Keuangan yang telah Diolah

Tabel 8 menunjukkan bahwa dengan perubahan periode kredit menjadi $2 / 10$ - n/45, laba kena pajak yang didapatkan oleh CV.Y menjadi lebih tinggi. Peningkatan laba tersebut salah satunya disebabkan oleh peningkatan penjualan sebesar $20 \%$.

Hasil wawancara dengan beberapa konsumen menunjukkan bahwa umumnya para pesaing CV.Y tidak memberikan diskon tunai, jika pun diberikan nilainya sebesar $1 \%$. Perubahan periode kredit dengan menetapkan periode diskon tunai memberikan nilai tambah bagi perusahaan yang menjadi "rangsangan" untuk konsumen dalam melakukan dan membayar pembelian kredit, ditambah dengan diskon tunai sebesar $2 \%$ yang melebihi diskon tunai yang diberikan oleh pesaing.

Selain itu, dengan periode kredit $\mathrm{n} / 45$, Lama penagihan perusahaan sama dengan rata-rata periode tagih industri yakni 45 hari. Hal ini membuat kelonggaran bagi para konsumen dalam melunasi pembelian kredit.

\section{Simpulan dan Saran}

\section{Simpulan}

Adapun dari hasil penelitian dapat disimpulkan:

1. Laba dan penjualan kredit merupakan suatu hal yang berhubungan positif. Kenaikan 1 Rupiah dari penjualan kredit akan meningkatkan laba perusahaan. Sedangkan pada neraca, semakin baik kebijakan penagihan, piutang dapat terkendali meskipun penjualan kredit meningkat. Hasil dari laporan arus kas menunjukkan bahwa penurunan piutang meningkatkan kas bersih perusahaan.

2. Perhitungan menunjukkan bahwa ketika memperlambat tenggat pembayaran, penjualan diproyeksikan meningkat. Bukan hanya dari sisi penjualan, namun setiap periode kredit menimbulkan biaya-biaya yang berhubungan dengan pengontrolan penagihan piutang. Setiap periode kredit membawa perusahaan pada tradeoff antara peningkatan pendapatan dan peningkatan biaya. 
3. Hasil perhitungan menunjukkan bahwa ketika perusahaan melakukan perubahan persyaratan kredit dalam bentuk periode kredit dari $\mathrm{n} / 30$ menjadi $2 / 10-\mathrm{n} / 45$, perusahaan berhasil meningkatkan laba. Persyaratan kredit 2/10 $-\mathrm{n} / 45$ memberikan nilai tambah bagi perusahaan karena rata-rata pesaing tidak memberikan periode diskon tunai, dan jika pun diberikan diskon tunai yang ditawarkan tidak melebihi $2 \%$.

\section{Saran}

Setelah melakukan simulasi perubahan periode kredit, dapat diajukan beberapa saran bagi CV.Y, diantaranya:

1. Semakin meningkatnya penjualan kredit, perusahaan dihadapkan pada kenaikan piutang ragu-ragu. Penjualan kredit yang tinggi dan lamanya penagihan, menjadi pertanda bagi CV.Y untuk memastikan manajemen piutang berjalan dengan baik. Manajemen piutang perlu untuk disesuaikan dalam setiap industri. Ketika ratarata periode pembayaran industri adalah 45 hari, sebaiknya perusahaan menetapkan periode pembayaran minimal selama 45 hari, hal ini akan mempengaruhi preferensi pembelian konsumen.

2. Setiap perubahan periode kredit menghadapkan perusahaan pada kondisi yang berbeda-beda. Periode kredit 2/10 - n/45 membawa CV.Y mendapatkan proyeksi penjualan tertinggi. Longgarnya periode kredit yang diberikan membuat perusahaan dihadapkan pada rata-rata keterlambatan pembayaran piutang selama 5 hari. Selain itu dengan diskon $2 \%$ selama 10 hari, $40 \%$ konsumen diproyeksikan akan mengambil diskon tunai. Trade-off peningkatan pendapatan dan biaya dalam setiap periode kredit yang ditawarkan menunjukkan bahwa persyaratan kredit 2/10 - n/45 sebaiknya dipertimbangkan oleh perusahaan.

3. Hasil perhitungan menunjukkan bahwa ketika perusahaan melakukan perubahan persyaratan kredit menjadi $2 / 10-n / 45$, CV.Y berhasil meningkatkan laba. Maka, sebaiknya CV.Y melakukan perubahan persyaratan kredit dari $\mathrm{n} / 30$ menjadi $2 / 10-\mathrm{n} / 45$.

\section{Daftar Pustaka}

Gitman, L. J. dan C. J. Zutter. (2015). Principles of Managerial Finance, $14^{\text {th }}$ ed. Boston: Pearson Education, Inc.

Higgins, Robert. (2012). Analysis For Financial Management. 10th ed. New York: The McGraw Hill Companies, Inc.

Ikatan Akuntan Indonesia. (2009). Standar Akuntansi Keuangan : PSAK No. 1 - Penyajian Laporan Keuangan. Jakarta : Salemba Empat.

Leach dan Melicher. (2015). Entrepreneurial Finance. $5^{\text {th }}$ ed. South Wester: Cengahe Learning.

Sekaran, Uma dan Bougie, R. (2013). 6th ed. Reseach Methods for Business. Jakarta : Salemba Empat.

Sundjaja, R. S., Barlian, I., Sundjaja, D. P. (2013). Manajemen Keuangan 1. Edisi 8 cetakan ke 2. Jakarta : Litera Lintas Media.

Weygandt, Jerry., Warfield, Terry D. Kieso, Donald E. (2015). $15^{\text {th }}$ Edition. Financial Accounting. IFRS Edition. USA : John Wiley \& Sons, Inc. 